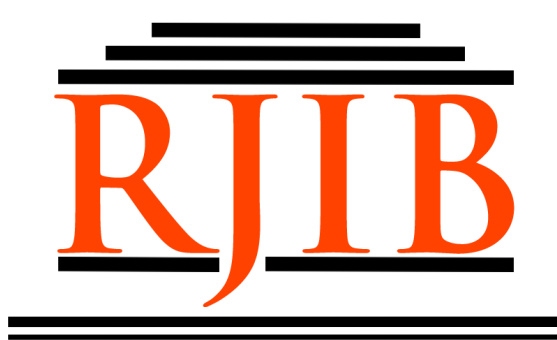

RETORIKA: Jurnal Ilmu Bahasa

Vol. 6, No. 1 April 2020, Page 63-68

\title{
Overcoming Implicit Meaning in Indonesian-English Translation
}

\begin{tabular}{|c|c|c|}
\hline \multicolumn{3}{|c|}{$\begin{array}{l}\text { Faculty of Letters, Universitas Warmadewa, Denpasar, Bali-Indonesia } \\
\text { madesusini@yahoo.com }\end{array}$} \\
\hline Received: 04/03/2020 & Revised: $21 / 04 / 2019$ & Published: $24 / 04 / 2020$ \\
\hline \multicolumn{3}{|c|}{ How to cite (in APA style): } \\
\hline \multicolumn{3}{|c|}{$\begin{array}{l}\text { Susini, M. (2020). Overcoming Implicit Meaning in Indonesian-English Translation. RETORIKA: Jurnal Ilmu Bahasa, } \\
\text { (1), 63-68. doi: https://doi.org/10.22225/jr.6.1.1646.63-68 }\end{array}$} \\
\hline
\end{tabular}

\begin{abstract}
Implicit meaning is one of the language phenomena which need overcoming in translation. This present study aims to investigate in what construction the implicit meaning is realized in Indonesian and how implicit meaning is handled when it is rendered into English. This study applied a descriptive qualitative approach. The data were taken from a book of Indonesian short stories entitled Mandi Api (Soethama, 2006) and its translation in English entitled Ordeal by Fire (Cork, 2008). The results of the research showed that implicit meaning in Indonesian texts is conveyed into English in two ways. Firstly, the implicit meaning is kept implicit. Secondly, it is realized in explicit construction. The implicit information of the source texts is made explicit in target texts for some reasons which include grammatical reason, semantic reason, and stylistic reason. In conclusion, although the source and the target texts have different constructions in the translation under study, the source meanings are successfully conveyed into English.
\end{abstract}

Keywords: Implicit meaning, implicit information, translation adjustments

\section{INTRODUCTION}

Every translation will have a goal. That is the target text must communicate the same meaning as the source text communicates. Translation studies always deal with meaning since it is meaning which is transferred from the source texts into the target texts. Meaning is the kingpin in translation studies (Bell, 1991). To be able to transfer the meaning adequately, one must be aware that not all of the meaning which is being communicated is stated overtly. There is meaning which is expressed explicitly and there is meaning which is left implicit. Implicit information implies that the information is not stated in an explicit form in the text itself (Larson, 1998). The information is shared information which may include shared language structure, culture, previous conversations, a common experience, etc. There are a number of constructions which have implied information. Those include: passive constructions, abstract nouns, genitive constructions, and metaphor. Beekman and Callow (Larson, 1998) mentions that the implicit information can be derived from the immediate or remote context in the document or from the cultural context.

The problem of implicit meaning and explicit meaning in translation must be well handled by a translator. This is perhaps one of the most difficult aspects in the translation process. If the translator fails in handling this, the target texts will sound non idiomatic or unnatural to the target language readers. On the other hands, the goal of the translator is to be accurate in representing the meaning of the source text, and, at the same time, to use the natural idiomatic forms of the target language. When one translates one text from one language into another language, some implicit information of the source language and culture will need to be made explicit. At the same time, 
some explicit information of the source text will need to be made implicit. Whether they will be implicit or explicit in the translation will depend on the natural forms used in the receptor language (Larson, 1998). It is also stated that implicit information may become explicit because of the grammatical, semantic, or stylistic adjustments. Larson's opinion is in accordance with translation adjustment proposed by (Hatim, 2001). The adjustment includes some modification techniques required to uphold translation equivalence. The translation adjustment suggested may involve: ignoring structural differences, achieving semantic harmony, and creating appropriate style.

A text having implicit information that one wish to translate is not stated in any explicit form in the text itself. However, the author and readers of the text have this information in common, or it is old information already mentioned elsewhere in the text. This old information cannot be found easily because the information is not always derived from the immediate context in the document.

Since implicit meaning is commonly faced by a translator in the translation in which its implied information can be derived from some places in the text, it needs to be discussed. This study discusses some constructions which have implied information and what adjustments are made by translator to transfer this meaning and for what reasons the translator made the implicit information explicit in the translation. This is what makes this present study different from the previous researches conducted by other researchers (Sato, 2015; Xia, 2015).

Other related studies have been carried out by (Zulprianto, 2014) which examines Translating Implicit Meaning of English Texts into Indonesian. This research attempts to examine how these cohesive markers are translated by analyzing some Indonesian translations of different short stories by Oscar Wilde. The result of this study demonstrates the translators tend to keep the implicit meaning of the source language (SL) in the target language (TL). This may owe to two explanations: the translators are not aware of the implicit information in the SL and are tempted to employ literal translation. However, the explanation by no means discredits the translators as they may deliberately translate so and their translations are possible in the structure of the TL. Furthermore, (Apriyanti, Wulandari, Safitri, \& Dewi, 2016) also conducted the similar study entitled "Translating Theory of English into Indonesian and Vice-Versa". This study is aimed at providing translating theory of English into Indonesian and vice versa. In achieving the aim, content analysis of expressive (poem), informative (report and academic), and vocative text (advertisement) is applied. The result shows that the translator needs to adapt the grammatical structure, cultural words, and writing mechanic of source language into target language. However, there are exceptions in cultural words and capitalization. In translating from English into Indonesian especially in academic text, some English words are assimilated into Indonesian (foreignization). In translating Indonesian poem into English, the target text capitalization imitates source text capitalization. Besides, for the purpose of attractiveness, persuasion, and effectiveness in translating Indonesian advertisement into English, different words are prefered but the meaning is retained. Thus, based on the background and the latest related studies above, this present study aims to investigate in what construction the implicit meaning is realized in Indonesian and how implicit meaning is handled when it is rendered into English.

\section{METHOD}

The data of this research were taken from a book of Indonesian short stories entitled Mandi Api (Soethama, 2006) and its translation in English entitled Ordeal by Fire (Cork, 2008). This study applied a descriptive qualitative approach. The source texts were examined to identify the constructions having implicit forms. The implicit constructions were then examined to find out their implied meaning. It was carried out by making the constructions explicit. To investigate how the source texts having implicit meaning were rendered into English, the source and the target texts were compared. When the target texts have implicit constructions, they were also turned into a form having explicit constructions.

\section{RESULTS AND DISCUSSION}

Indonesian texts contain implicit information realized in the constructions which include passive construction, abstract noun, genitive construction, and ellipsis. Those texts are rendered into English in two ways. Firstly, the implicit information is made explicit in target language. Secondly, the implicit information is left implicit in target language. 
Implicit Information is Made Explicit

Some source language texts having implied information are made explicit in the target language.

Implicit Information in Passive Construction

- SL: Harus dijelaskan dengan jujur mengapa upacara perkawinan diulang. (Soethama, 2006, p. 165).

- TL: They would have to explain honestly why the marriage ceremony had to be repeated (Cork, 2008, p. 3).

The source language text contains a clause in passive construction which is characterized by the verb dijelaskan. There is information which is implied in this construction. The complete information can be seen from its active construction: Mereka harus menjelaskan dengan jujur mengapa upacara perkawinan diulang. In this construction the agent of the sentence (i.e. mereka) is not stated overtly because it is already mentioned elsewhere in the text. The agent is information which is implied. In the target language all the information is explicitly stated, including the agent. To the readers of target language, it would be ungrammatical if the SL text is directly translated into passive sentence without any subject. So, to make it grammatical, the subject must be mentioned and the translator decides to use active sentence by positioning the subject they, as the equivalent of mereka) as the topic which needs to be emphasized. The purpose is to establish semantic harmony of the text. Seen from the meaning transferred, both texts have the same meaning. The translation is idiomatically done.

- SL: ..., hari baik itu tak pernah disepakati. Dua keluarga itu tak kunjung bersetuju (Soethama, 2006, p. 166).

- TL: ... the two families were not able to agree on an auspicious day. Finding common ground between them became harder and harder (Cork, 2008, p. 4).

Implicit information in the source language is represented by the passive form of the sentence by using the verb disepakati. This construction implies that there is some information implied. The underlying information of this construction is: Dua keluarga tak pernah menyepakati hari baik itu. The implicit information, that is dua keluarga as the agent, is derived from the immediate context in the text. It is clearly stated in the following sentence represented by Dua keluarga itu tak kunjung bersetuju. When the implicit information in this passive sentence is transferred into the target language, the translator makes it explicit. To create idiomatic translation, the implied information is made to be overtly stated and, the agent is made to be the topic of the sentence to establish the semantic harmony of the text. Basically, the two texts convey the same meaning.

\section{Implicit Information in Abstract Noun}

- SL: "Membubuhi tanda tangan, saya tak mau, " ujar Ledang. "Itu sudah penipuan namanya” (Soethama, 2006, p. 152).

- TL: "I can't put my signature on them," said Ledang. "That would be deceiving people" (Cork, 2008, p. 117).

There is implicit information implied in the abstract noun penipuan. The underlying construction of this information is: Sesuatu menipu orang-orang. The implied information can be derived from the immediate context of the text. It is clearly stated in the sentence before it. To make the meaning constant in the target language, the translator makes this implicit meaning explicit. The information is overtly stated by using grammatical structure and lexical items of the target language. The text to be translated needs to be paraphrased to help the readers easier to understand the text. The translator expresses this abstract noun in this way to emphasize what deceived people and who was deceived by something. In other words, this strategy is to create the same emotive effect.

- SL: Ia melihat dan merasakan persamaan mimik ayahnya? ... (Soethama, 2006, p. 26).

- TL: He could see and feel that he looked and moved like this man?... (Cork, 2008, p. 100).

Mimik as an abstract noun contains information which is implicit. The meaning of this abstract noun is: How someone looks and moves. In the target language the translator makes it explicit by stating all the information overtly. This implicit meaning becomes explicit because of grammatical reason. There is no lexical item in English used to refer to how someone looks and moves. So, to achieve an idiomatic translation, the word needs paraphrasing.

\section{Implicit Information in Genitive Construction}

- SL: Tak sedikitpun dalam fisiknya menyisakan bau orang Indonesia suku Bali. Kerug benar-benar telah menjadi Maeda. Logat Jepang-nya pun kental sekali 
(Soethama, 2006, p. 23).

- TL: There was nothing about his physical appearance to remind anyone of his Balinese origins. Wayan Kerug had truly become Maeda. He even spoke with a Japanese accent (Cork, 2008, p. 97).

Implicit information is found in the source language text represented by the genitive form logat Jepang-nya. If the information is explicitly stated, it will become is: Dia berbicara dengan logat Jepang. In the surface structure berbicara is not stated. In Indonesian logat always implies berbicara. In the target language the implicit information is made explicit. The implied information is explicitly stated to establish semantic harmony. By this strategy, the translator can make the translation sound natural to the readers of the target language and the text can be clearly understood.

\section{- SL: "Kamu pasti tahu rumah Pak Gusti".}

"Tentu, Maeda-san juga akan tahu, nanti kita akan makan siang di sana. Rumahnya besar sekali, ... " (Soethama, 2006, p. 27).

- TL: "I am sure you know where he lives?".

Certainly, and you will also get to see his house because you will be having lunch there. The house is very big ... "(Cork, 2008, p. 101).

The genitive construction in the source language text has implicit meaning because there is information implied behind this construction. If this information is overtly stated, rumah Pak Gusti will mean Pak Gusti bertempat tinggal di rumah itu. The information which is implicit is bertempat tinggal. In target language this implicit information is overtly stated by the use of the verb lives which is considered to have the same meaning with bertempat tinggal. The translator tries to achieve an idiomatic translation and to establish semantic harmony by this strategy.

\section{Implicit Information in Ellipsis}

- “... ia duduk di tempat terhormat. Kita di lantai, $\quad$ ia di balaibalai" (Soethama, 2006, p. 1).

- “... she will sit in a place of honour; we will sit on the floor, she will sit up high (Cork, 2008, p. 83).

The source language text is in the form of ellipsis. This construction implies that some elements are not overtly stated. If it is not in the form of ellipsis, the construction becomes: Kita $d u d u k$ di lantai, ia $d u d u k$ di balai-balai. Duduk is as the implicit information in the source language. This implied information is derived from the immediate context of the texts represented by the clause ia duduk di tempat terhormat. The translator transfers this implicit meaning by restructuring it in complete form. In other words, the implicit meaning is made explicit in target language. This version is chosen to give emphasize on the action of sitting. By this, the translator wants to establish the semantic harmony of the text.

- SL: ... Kadek harus melalui pergulatan pertimbangan sebelum memutuskan menjadi orang puri (Soethama, 2006, p. 1).

- TL: ... Kadek had to consider before she could decide to become a member of a noble family (Cork, 2008, p. 83).

The source language text belongs to ellipsis sentence. Because of this, there will be some information which is implicit. The implicit information is Kadek. This can be derived from the immediate context. The complete information is: Kadek harus melalui pergulatan pertimbangan sebelum Kadek memutuskan menjadi orang puri. She in the target language as the equivalence of Kadek is overtly stated. The sentence is not in ellipsis sentence. The translator gives emphasize to the subject 'Kadek' by mentioning it twice by using noun Kadek $\mathrm{n}$ pronoun she. It aims at creating the same emotive effect.

\section{Implicit Information is Left Implicit}

The implicit information of the SL texts which is left implicit in the TL is realized in passive, genitive, abstract noun, and ellipsis construction.

- SL: Cottages itu sudah selesai dibangun (Soethama, 2006, p. 68).

- TL: The cottages have been finished (Cork, 2008, p. 111).

The source language text is in the form of passive sentence. This form shows that there is some information which is not stated in explicit form. Explicitly, the information is Seseorang sudah selesai membangun cottages $i t u$. In this case the agent is not stated overtly or it is implicit information. The translator transferred the meaning of the source language text into the target language by passive construction. That is the cottages have been finished. This construction implies that Someone has finished building the cottages. The translator applies this strategy with the consideration that he does not need to mention 
the agent of the passive sentence in target language because by this form the readers of the target language can clearly understand the text. That is why the implicit meaning is left implicit in target language. By this construction, the information load in target language text can be avoided.

- SL: Aku kemudian dianjurkan Durma membangun gubuk beratap ilalang di tepi jalan, ....Sedikit-sedikit kugantung cindera mata di gubukku, .... 2006, p. 65).

- TL: Durma gave me the idea of building a little thatched hut at the side of the road .... Soon I started putting little souvenirs in my hut, ... (Cork, 2008, p. 109).

The implicit meaning which occurs in the source language text is represented by a genitive construction gubukku. It has implicit meaning because there is implied information in this construction which is not stated explicitly. It is derived from the immediate context which occurs before it. If it is not in implicit form, the information can be in the form of gubuk tempat saya tinggal. Tempat tinggal as the implied information is transferred by the translator into the target language in the same form, that is genitive construction my hut. This form also has implicit meaning because it has implied information. Its implied information is in the context before it. If the information is overtly stated, it will be the hut where I live. The implied information where and live is left implicit in target language because the construction chosen sounds natural to the readers of the target language and it is to avoid information load. Besides, the information is shared information. Because it is a kind of old information, it is not necessary to make it explicit.

- SL: "Tapi ini kesempatan, De. Ingat, kesempatan tidak datang dua kali...." Sepekan lamanya ia mempertimbangkan saran Ketut Geria (Soethama, 2006, p. 152).

- TL: "But this is an opportunity, De. Remember - opportunity doesn't knock twice...." Ledang thought about Ketut Geria's suggestion for a week (Cork, 2008, p. 117).

Saran Ketut Geria is a kind of genitive construction. It shows implicit meaning because it has information which is implied behind this construction. The complete information is Ketut Geria memberi saran kepada seseorang. Its implicit information occurs in the context before it. This implicit meaning is transferred to the target language. It also occurs in the form of construction, that is Ketut Geria's suggestion. It also has implied information which can be found in the context before it. The complete information is: Ketut Geria gives someone suggestion. This means that implicit information is left implicit. The translator decides to apply this strategy because by this form the readers of the target language can understand the text.

- SL: Kutangkap kengerian di antara kepasrahan matanya (Soethama, 2006, p. 68).

- TL: I saw fear and resignation there (Cork, 2008, p. 112).

The source language text has implicit meaning represented by abstract noun kengerian. Some information is not stated overtly in this construction. The explicit information is orang merasa ngeri terhadap sesuatu 'someone feels frightened to something'. The text which contains implicit meaning is transferred into the target language by the same form. The target language also uses abstract noun fear to mean kengerian. Fear also has implied information. It can be seen from its meaning. That is someone feels frightened to something. The translator applies this strategy because this form is natural for the readers of target language. The information is already mentioned elsewhere in the text, so it is old information. Since it is clearly understood by the readers, the implicit meaning is left implicit in the target language.

- SL: ... seorang lelaki berkumis tebal menuruni tebing, berhenti di depan rombongan (Soethama, 2006, p. 26).

- TL: ... a man with thick moustache came down and stopped in front of the group (Cork, 2008, p. 100).

The source language text is in the form of ellipsis. This form implies that there are some elements left out. This also means that some information is not explicitly stated. The complete information is seorang lelaki berkumis tebal menuruni tebing, setelah lelaki berkumis tebal itu tiba di depan rombongan, lelaki berkumis tebal itu berhenti di depan rombongan. The translator also restructures this meaning in the target language by using ellipsis construction. This form also has implied information. It can be derived from its complete form. That is a man with thick moustache came down and after a man with 
thick moustache was in front of the group, a man with thick moustache stopped in front of the group. To achieve idiomatic translation the implicit meaning in the source language is left implicit in the target language. By this form the readers of target language can clearly understand the text because the information implied is already mentioned elsewhere in the text. So it is a kind of old information.

The texts to be translated may contain implicit meaning. The implicit information of the Indonesian texts is overcome by the translator in two ways. Firstly, the implicit meaning is made explicit. Secondly, the implicit meaning is left implicit in the target language. How the SL meaning is realized in $\mathrm{TL}$ is due to some reasons. For instance, in Indonesian it is acceptable to convey passive imperative by not stating the subject such as in Harus dijelaskan dengan jujur mengapa upacara perkawinan diulang, but not in English. Subject in English is a must in a sentence construction. As a consequence, the TL text must be arranged with subject and in the translation above the translator rendered it in active construction They would have to explain honestly why the marriage ceremony had to be repeated. This shows that the adjustment made is because of grammatical reason. In this TL text the subject they is used to make the text grammatical.

\section{CONCLUSION}

Based on the objectives and results obtained, thus it can be concluded that Indonesian texts having implicit constructions are rendered into English in some ways. In some cases they are kept implicit and in others they are turned into constructions having explicit meanings. Although the source and the target texts have different constructions in the translation under study, the source meanings are successfully conveyed into English. Indonesian texts contain implicit information realized in the constructions which include passive construction, abstract noun, genitive construction, and ellipsis.

\section{REFERENCE}

Apriyanti, T., Wulandari, H., Safitri, M., \& Dewi, N. (2016). Translating Theory of English into Indonesian and Vice-Versa. Indonesian Journal of English Language Studies, 2(1), 38-59. Retrieved from https:// repository.usd.ac.id/23327/1/4257_Translati ng+Theory-IJELS.pdf

\section{York: Longman.}

Cork, V. (2008). Ordeal by Fire. Denpasar: Arti Foundation.

Hatim, B. (2001). Teaching and Researching Translation. England: Pearson Education Limited. Retrieved from http:// englishlangkan.com/produk/E Book Teaching and Researching Translation Basil Hatim 2013.pdf

Larson, M. L. (1998). Meaning-Based Translation. Lanham: University Press of America.

Sato, E. (2015). Metaphor and Translation Prisms. Theory and Practice in Language Studies, 5 (11), 2183-2193. Retrieved from http:// dx.doi.org/10.17507/tpls.0511.01.

Soethama, G. A. (2006). Mandi Api. Denpasar: Buku Arti.

Xia, X. (2015). Meaning in Context and Nature of Translation. Theory and Practice in Language Studies, 5(3), 652-656. Retrieved from http://dx.doi.org/10.17507/tpls.0503.28.

Zulprianto. (2014). Translating Implicit Meaning of English Texts into Indonesian. In Language Awareness on TEFL for Multilingual Learners (pp. 529-535). Padang: Universitas Negeri Padang. In Language Awareness on TEFL for Multilingual Learners (pp. 529-535). English Department Universitas Negeri Padang.

Bell, R. T. (1991). Translation and Translating. New 